A re-evaluation of wetland carbon sink mitigation concepts and measurements: A diagenetic solution

John Barry Gallagher ${ }^{1} \cdot$ Ke Zhang $^{2}$. Chee Hoe Chuan ${ }^{3}$

John Barry Gallagher

${ }^{1}$ Institute for Marine and Antarctic Studies, University of Tasmania, Australia, 7000

Orcid ID: 0000-0002-2622-0912.

johnbarry.gallagher@utas.edu.au \& johnbarrygallagher@icloud.com.

Ke Zhang

${ }^{2}$ State Key Laboratory of Lake Science and Environment, Nanjing Institute of Geography and Limnology, Chinese Academy of Sciences, Nanjing, PR China, 210008

Orcid ID 0000-0002-1841-9016.

Chuan Chee Hoe

${ }^{3}$ Borneo Marine Research Institute, Universiti Malaysia Sabah, Jalan UMS, Kota Kinabalu, Sabah, Malaysia, 88400

Orcid ID 0000-0003-4715-5387. 


\title{
A re-evaluation of wetland carbon sink mitigation concepts and measurements: A diagenetic solution
}

\begin{abstract}
The capacity of wetlands to mitigate greenhouse gas $(G H G)$ emissions is the sum of two services-the protection of vulnerable organic stocks from remineralisation, and the capacity to sequester GHGs relative to their anthropogenic replacements. Organic carbon accumulation $(C A)$ down through the sediment column is often taken as the measure of sequestration because of its capacity to record long-term variability and trends. However, we demonstrate that: i) $C A$ is not equivalent to sequestration as net ecosystem production $(N E P)$ for open systems; it requires the subtraction of the initial deposition rate of labile allochthonous carbon sources; ii) $C A$ also requires subtraction of intrinsically allochthonous recalcitrants down through the sediment column, and together with subtraction of autochthonous recalcitrants from organic stock services; iii) $C A$ as a climatic mitigation service also requires a diagenetic correction, as the annual deposition of labile organic carbon continues to remineralise over the long-term; and iv) preserving of a wetland has a significantly greater mitigation potential than restoring one. To address the above concerns, a global diagenetic solution is proposed, applied, and tested for a tropical seagrass and mangrove. As expected traditional $C A$ estimates were disproportionately larger than their respective cal. NEPs and together with stocks fell within the ranges reported in the literature, with a final carbon accreditation highly dependent on the choice of their anthropogenic replacements. The review demonstrates that mitigation concepts and measurements for natural carbon sequestration solutions require re-evaluation to avoid $G H G$ emissions above their capacity or reduce the ability to fulfil emission targets.
\end{abstract}

Keywords: blue carbon · teal carbon $\cdot$ black carbon $\cdot$ carbon accumulation $\cdot$ carbon sequestration $\cdot$ carbon stocks - net ecosystem production $\cdot$ allochthonous recalcitrants $\cdot$ autochthonous recalcitrants $\cdot$ protection $\cdot$ restoration

\section{Introduction}

Anthropogenic greenhouse gas $(G H G)$ emissions are largely responsible for climate change and will likely disrupt both society and global ecosystems (Hoegh-Guldberg et al. 2018). This has led to calls to mitigate these emissions (UNFCCC, 2015). Several mitigation practices have been suggested, ranging from increasing the efficiency and reliance on the burning of fossils fuels, carbon capture storage, and the restoration and conservation of existing natural carbon sinks (Lal 2008). However, there is also a realisation that relying on altruism may not be sufficient and mitigation requires incentives. Carbon trading is one such mechanism. It can to used to fund projects and move the costs of carbon offsets to industry towards more efficiency or reliance on fossils fuels. In contrast, to engineered processes, such as carbon capture and storage. natural solutions from the preservation or restoration 
of a healthy ecosystem have the necessary vigour, resilience, and self-organization to sustain itself (Costanza \& Mageau 1999; de Paoli et al. 2017), along with its carbon sinks. Consequently, there has been a push for extensive replanting and protection of terrestrial forests worldwide (Mackey et al. 2008).

While valuable, forests support a relatively low carbon production density (Lal 2008) and are vulnerable to fire. These constraints are not as apparent for wetlands both inland marshes and coastal canopy systems mangroves, seagrass, and salt marsh (Duarte et al. 2010). Furthermore, these systems support a significant fraction of their terrestrial and marine carbon sinks confined within a relatively small area. Inland wetlands - Teal carbon systems (Zinke 2020) - occupy an area between $2 \%$ to $5 \%$ of the land and store between $20 \%$ and $30 \%$ of organic carbon of the terrigenous landscape (Kayranli et al. 2010). Similarly, coastal canopy wetlands - Blue carbon systems (Zinke 2020) - occupy $<2 \%$ of the marine seascape, and are estimated to contribute around $50 \%$ of the ocean's organic carbon storage, largely within an accreting soil-sediment column (Duarte et al. 2005). Although the magnitude of this claim has been disputed (Johannessen and Macdonald, 2016). This makes these ecosystems valuable and manageable but also vulnerable given their relatively small areas. Understandably, an accurate assessment of these ecosystems' mitigation potential is required for any carbon offset standard. This would seem a requirement to see real mitigation impacts but also for confidence in market-based and national compliance schemes. Ground-based surveys and satellite observations can provide accurate accounts of their extent, however, we contend that misunderstandings and errors have arisen in the foundations behind wetland mitigation services. First, there is an implicit and untested assumption that total sedimentary organic carbon accumulation is a proxy for carbon sequestration. Second, the majority of carbon sink assessments still fail to subtract a full range of possible intrinsically recalcitrant allochthonous or autochthonous carbon from stocks and sequestration estimates (Chew and Gallagher 2018; Rillig 2018). Third, the traditional conceptual model does not account for the remineralisation of its sedimentary organic carbon over climatic time scales (Chuan et al. 2020; Maher et al. 2017). Fourth, major reviews continue to equate an ecosystems' organic carbon stocks as the measure of its mitigation service without reference to a likely anthropogenic replacement (e.g. Macreadie et al 2021; McLeod et al. 2011), although see wetland Verified Carbon standards (Needelman et al. 2018). Fifth, Verified Carbon Standards appear to equate the loss or gain of carbon stocks for respective preservation and restoration as the only measure of wetland mitigation of GHG emissions (Needelman et al. 2018), without demonstrating the relationship with the net carbon blance of the ecosystem as an additional service (e.g. Siikamäki et al. 2013; Tokoro et al 2014) or a constraint (Praire et al 2018). 


\section{Aims}

The article aims to review the measurement of carbon stock and sequestration concepts and clarify the additional constraints needed to qualify as a mitigation service. The currently-favored methods for stock and sequestration are outlined; constraints and methods discussed, and sequestration misconceptions addressed for different circumstances for systems closed and open to allochthonous inputs. We then demonstrate what would be required to measure true sequestration and stock variability over climatic time scales from the sedimentary record, and argue for an additional mitigation concept for future discussion and testing. Finally, these concepts are implemented and evaluated using two disparate examples, namely, a tropical submerged seagrass meadow and an intertidal mangrove wetland both open to different amounts and forms of allochthonous organic carbon.

We also acknowledge but do not address other factors that can be considered as an adjunct or constraint to a wetlands' proclivity to sequester carbon. These include the uncertain fate of organic carbon export and its downstream impacts (Prairie et al. 2018), the uncertain roles of $\mathrm{CO}_{2}$ production and loss during biogenic and geogenic calcium carbonate formation or redissolution between their respective canopy and anthropogenic nonvegetated replacements (Howard et al. 2018; Mitsch et al. 2013), and the biogenic production and emissions of other greenhouse gases other than $\mathrm{CO}_{2}$. These have already been addressed as emission factors within the carbon accreditation process (Needelman et al. 2018). Finally, no consideration is given to the inputs of dissolved inorganic carbon (DIC) from adjacent rivers (Chapin et al. 2006), and coastal upwelling. While these may also play a role in the ecosystems' carbon balance to the atmosphere (Tokoro et al. 2014), these are also ecosystem site parameters and are largely independent of the differences between biological drivers of sequestration relative to their anthropogenic replacements.

\section{The role of sediment carbon stocks in mitigation}

Within the confines of the voluntary and compliance carbon markets, a wetlands' ability to mitigate carbon emissions is considered as the loss of organic stock as a preservation service, or a gain of stock to justify restoration (Needelman et al. 2018). Translated as a sequestration service that loss or gain is the time it takes for its anthropogenic replacement or restoration to establish itself at a steady-state at equilibrium. Or more succinctly, the mean equilibrium state, as described by variance along a stationary time series. The length of which will ultimately respond to ongoing climate variability (Gallagher 2017; Marba and Duarte 11997). However, not all organic stocks are vulnerable to remineralisation (Jennerjahn 2020). Leaving aside a case-by-case fate and loss of biomass, for example, mangrove wood may be stored as a product or burnt for charcoal (Eong 1993). The fate of the remaining sedimentary stocks is largely determined not only by their intrinsic vulnerability to remineralisation, 
between $25 \%$ and $100 \%$. (Pendleton et al. 2012), but to a depth of disturbance and oxidation. Once the vulnerable stock fraction and its extent have been estimated $\left(\mathrm{gC} \mathrm{m}^{-2}\right)$, the values are then transformed to a vector quantity $\left(\mathrm{gC} \mathrm{m}^{-2} \mathrm{yr}^{-1}\right)$ in the time it takes for the vulnerable fraction to be remineralised. The time has been set as a default of 20 years (IPCC 2014) to reflect the period over which the replacement ecosystem will establish itself at steadystate equilibrium. For a first-tier assessment, the depth of disturbance is commonly set to a maximum of $1 \mathrm{~m}$ irrespective of its total column depth.

The depth of disturbance and the extent of remineralisation, however, will ultimately depend on its type of anthropogenic replacement (Siikamäki et al. 2013). For example, a mangrove forest can lose up to1.5 m to $3 \mathrm{~m}$ of sediment to aquaculture ponds, piled up and directly exposed to the weather on top of its banks (Järviö et al. 2018). Alternatively, the loss of a natural seagrass meadows' canopy to disease has directly progressed to a rocky barren ground state (Wilson 1949). It is also conceivable that the wetlands anthropogenic replacement may support a larger organic stock inventory. For example, mangroves have encroached onto salt marshes due to sea-level rise (Rogers et al. 2005). Ironically, preserving the original salt mash in the face of anthropogenic-driven sea-level rise could potentially exacerbate and not mitigate $G H G$ emissions. However, it could also be argued that the replacement mangroves are also potentially vulnerable to anthropogenic decisions which could lead to their clearance (Chee et al. 2017). Under these circumstances, preservation of the threatened salt marsh (SM) stock inventory could be justified. That is to say, when the value in preserving the mangrove (M) from a disturbed system less stock inventory (DS) is less than the salt marsh (i.e. (M - DS) - SM; where SM < M and DS < SM). The actual fraction and disturbance depth will likely reflect the difference in sedimentary organic stock content of a likely anthropogenic replacement from that area; assuming little export from the site previously occupied by the wetland.

\section{Measuring carbon stocks.}

The attraction of focusing only on standing stock measurements comes from their relative simplicity. This is an important attribute to capture the inherent variability for some systems (Hu et al, 2021). For example, there is a simplicity in that estimates of tree biomass can be made using accessible allometric width, carbon content, bulk density parameters. Except for intermediate and faster-growing R-strategist macrophytes, the timing for both biomass assessments is usually not that critical during the year or between years. This is because it would decades to a century for accumulation to contribute a significant fraction of the stock inventory to $1 \mathrm{~m}$ depth (Wilkinson et al. 2018) and are not likely to change significantly between years irrespective of the canopy species. Furthermore, after taking sediment cores, a selected number of horizons of a few $\mathrm{cm}$ thick can be easily sampled 
or physically mixed to integrate variation with depth. Once the sediment samples are dried, the analysis can be handled through more specialised laboratory services. This service can be readily extended to the analysis of organic stable isotope signatures to estimate the fractions of different sources (Gonneea et al. 2004). Alternatively, a less resource-intensive approach uses organic carbon proxies. These can be dry bulk density (Callaway et al. 2012), gravimetric losses after combustion, chemical oxidation and titration (Byers et al. 1978; Heiri et al. 2001), or infrared reflectance (Bellon-Maurel \& McBratney 2011). Except for chemical titration, the above proxies to some degree require a global (Fourqurean et al. 2012) or preferably regional (Craft et al. 1991) calibration with standard methods, with the inclusion of regression variance in the final estimate (Gallagher et al. 2021a).

\section{Limitations and misunderstandings of the stock concept}

Intrinsically recalcitrant organic carbon produced within or outside the ecosystem is not vulnerable to remineralisation after disturbance and so, do not contribute to a carbon stock mitigation service. In other words, only sedimentary carbon stocks vulnerable to remineralisation will release GHGs after disturbance and thereby only their continued presence can be considered as a mitigation service, irrespective of their origin. However, removing intrinsically autochthonous from the stock calculus has not yet been adopted other than recognition by the IPCC for allochthonous recalcitrants (Bindoff et al. 2019). Arguably the most ubiquitous of the intrinsic recalcitrants is black carbon (BC), for which, there is very little impediment to quantifying this component. The carbon content can be estimated after thermal or chemical isolation within a sedimentary matrix using standard laboratory equipment (Chew \& Gallagher 2018). Carbon and $\mathrm{N}$ isotopic signatures can then be used to assist in identifying their allochthonous or autochthonous nature (Gallagher et al. 2021a; Leorri et al. 2018). Nevertheless, $\mathrm{BC}$ estimates across coastal wetland ecosystems remain globally undersampled. This is despite contributing substantial fractions to the sediments' total organic carbon (TOC) (means between 3-38\%) (data from Chew and Gallagher 2018; Gallagher et al. 2021a; Gallagher et al. 2019). The variability reflects the supply of labile organic supply, relative to local pure BC supply from atmospheric deposition, advective loss from the canopy before deposition, and any intertidal loss after dissolution (Gallagher et al 2021). Estimates across freshwater wetlands, however, are scarce but may still be significant. Sediment and soil BC fractions between $35.9 \%$ and $41 \%$ of its have been reported within an industrial setting for ponds and paddies (Song et al. 2002).

Along with $\mathrm{BC}$, other intrinsically recalcitrant forms may require evaluation. These are kerogens, geologically old organic materials washed in from catchment shales, and plastics. Unfortunately, wetland measurements of sedimentary kerogens are restricted to a shallow pond and paddy field located within an industrial region (reportedly $24 \%$ and $30.8 \%$ of TOC respectively; Song et al. 2002). Similarly, information on the importance of 
microplastics is limited, although within industrial soils the plastic content can be substantial (6.7\% dry wt) and remains measurable between $0.1-5 \%$ of carbon content for soils away from direct human influence (Rillig 2018). However, for wetland sediments, no data is available. Nevertheless, during a sediment coring program, the author (JBG) has observed the presence of plastic bags buried within surface sediments of an intertidal urban seagrass meadow (Middle Bank, Penang, Malaysia). Within the same region, macroplastic debris was also observed to both cover and be retained on the surface sediments of urban and peri-urban mangrove forests (162 to 6763 items $100 \mathrm{~m}^{-2}$; Yin et al. 2020). Along with intrinsically recalcitrant material, labile material can become effectively recalcitrant from physical protection. This can occur within a sedimentary clay matrix. However, estimates put this association to $<5 \%$ of the TOC (Needelman et al. 2018), and it is not clear whether such associations remain recalcitrant when subject to continuous resuspension (Cathalot et al. 2013). Physical protection is also manifested from occluded carbon contained within the glassy structures of plant phytoliths. Within non-alkaline soils, phytolith-occluded carbon can represent most of the remains of organic matter (Parr \& Sullivan 2005). However, for aquatic systems, data is limited to two tropical river-estuarine systems. There biogenic silica within the water column or non-vegetated surface sediments is dominated by phytoliths (Cary et al. 2005; Zang et al. 2016).

\section{Carbon sequestration}

Sequestration occurs when the rate of ecosystem $\mathrm{CO}_{2}$ fixation exceeds the community respiration from the consumption of available organic carbon. When the biomass is at a steady-state, the excess organic carbon accumulates largely down a relatively rapid accreting sediment column (Prairie et al. 2018) The balance is referred to as the net ecosystem production $(N E P)$. Indeed, the shallow canopy can stabilise and preserve these sedimentary remains as stocks, which makes these ecosystems so valuable in comparison to terrestrial forests (Mcleod et al 2011). Like stocks, the amount sequestered should be compared to its anthropogenic replacement (Eq. 1). Together, both stock vectors and NEP concepts appear to describe how the preservation of these canopy wetlands can constrain $G H G$ emissions (Siikamäki et al. 2013).

$$
\text { Cmit }=\left(N E P+\frac{\theta}{\varphi_{1}} \text { Cstock }\right)-\left(N E P R r+\frac{\theta}{\varphi_{2}} \text { Crstock }\right)
$$

Eq. 1 Where Cmit is the $G H G$ carbon mitigation service and $N E P$ the annual atmospheric carbon dioxide sequestration rate, positive for uptake; Cstock represents biomass and sedimentary organic carbon stocks that have accounted for BC, with $\theta$ the vulnerable fraction likely to be remineralised over a time $\varphi$ to attain an equilibrium should the ecosystem be degraded or destroyed; NEPRr is the atmospheric carbon dioxide sequestration rate of the replacement ecosystem, and Crstock the organic carbon stock of the replacement ecosystem that has accounted 
for $B C$, with $\theta$ is the fraction vulnerable to remineralisation after destruction or disturbance, over time $\varphi$ for each circumstance. As equation (1) stands, it provides no information on what determines the extent of the balance, other than the net productivity of the plant. The carbon use or consumption will depend on the innate digestibility of the plant (Cebrian 2002) and any labile allochthonous material supplied to the ecosystem. Whereas, for the sediment deposits, the innate digestibility is constrained by the 'aging' of the organic mix within the sediments, and physical protection associated with the clay fractions (Burdige 2007). Clearly, unlike stocks, sequestration is more valuable for an ecosystem capable of both directing $\mathrm{CO}_{2}$ towards the production of autochthonous recalcitrants and the protection of labile fractions. Although it should be noted that gaseous emissions in the production of autochthonous BC would constrain its mitigation service (Santín et al. 2015). As in the case of stocks, allochthonous recalcitrants continue to play no role in the sequestration calculus; and to include these recalcitrants would amount to double-accounting across ecosystems (Needelman et al. 2018).

\section{Measuring sequestration}

Direct measurements of NEP are resource and knowledge-intensive. Carbon sink assessment programs require either numerous spatial and seasonal diurnal deployments of benthic chambers or measurements of the water columns' metabolic gases (Maher \& Eyre 2012; Gruber et al. 2011). Alternatively, continuous eddy covariance deployments on single benthic frames or atmospheric towers have been deployed (Lu et al. 2017; Rodil et al. 2019). The eddy covariance footprint can be more than $200 \mathrm{~m}$ long, but changes with wind direction require statistical imputation methods to effect a contiguous time series. However, while valuable, these approaches do not function on the time scale needed for estimating variance and trends over climatic scales. Furthermore, across intertidal systems fluxes immediately above the macrophyte assemblage fail to account for the lateral loss of $\mathrm{CO}_{2}$ from the deeper parts of the sediment column (Fig. 1c) (Maher et al. 2018).

In place of direct measurements, annual sedimentary organic carbon accumulation has been touted as a measure of sequestration. It reduces the need for specialised equipment and variability can be estimated down the sediment column over decades while accounting for any lateral losses of $\mathrm{CO}_{2}$. Incubation chambers and eddy covariance flux experiments cannot detect lateral emissions during intertidal exchange (Maher et al. 2018). Furthermore, sediment cores have the advantage of appearing to integrate accumulation rates extensively beyond their diameters. One core can closely represent the mean for a wetland, and wetlands across a region (Callaway et al. 2012). Once the core has been extracted, traditional estimates of carbon accumulation are then calculated as the product of horizon carbon concentration and their sediment accumulation rate (velocity) below a diagenetically active surface layer (Cebrian 1999; Johannessen and Macdonald 2018). Accumulation rates are usually calculated 
using global geochronological models from the supply and decay of the natural radioisotope ${ }^{210} \mathrm{~Pb}$ over the last 100 to 150 years (Lavelle et al. 1986). While historically known markers can be employed, a ${ }^{210} \mathrm{~Pb}$ geochronology has the advantage of providing sedimentation rates over climatic scales without the knowledge of its depositional history and is widely accessible as a laboratory service.

\section{Limitations and misunderstandings of sequestration down the sedimentary record}

Sequestration calculations using the product of the sediment accumulation rate and organic concentration appear to solve the issues associated with direct measurements of sequestration as their NEP. Indeed, carbon accumulation termed as sequestration is pervasive across wetland and estuarine science (e.g. Carnell et al. 2018; Chmura 2013; Forbrich et al. 2018; Mitsch et al. 2013; Murray et al. 2011; Murray \& Vegh 2012; Troxler 2013; Villa \& Bernal 2018; Weston et al. 2014). Likely as a consequence, the term sequestration within Verified Carbon Standards has also been given to the accumulation rate of sedimentary carbon stocks (Needelman et al. 2018). More recently it has also been applied to the accumulation rate of seaweed deposits sequestered to the deep ocean (Krause-Jensen et al. 2018; although see Gallagher et al. 2021b). It must be said, that some articles use the term sequestration with accumulation without explicitly stating an equivalency with $N E P$ (e.g. Carnell et al. 2018; Chmura 2013; Murray et al. 2011; Murray \& Vegh 2012; Villa \& Bernal 2018). Nevertheless, equivalency is often implied when comparisons are made with carbon accumulation or used to estimate lateral exchange of $\mathrm{CO}_{2}$ from vertical NEP measurements (e.g. Forbrich et al. 2018; Mitsch et al. 2013; Troxler 2013; Weston et al. 201).

The equivalency of sequestration with sediment organic carbon accumulation, however, is mistaken from three standpoints. First, most teal and some blue carbon ecosystems are heterotrophic from the consumption of allochthonous subsidies, yet continue to increasingly accumulate organic carbon down the sediment column (Prairie et al. 2018; Duarte \& Prairie 2005). Indeed, the only known example that we are aware (Tokoro et al. 2014) showed that recent annual sedimentary organic carbon accumulation of boreal seagrass meadows was on average around 35 times greater than their moderately autotrophic $N E P$ rates (recal. 5.5 and $0.16 \mathrm{gC} \mathrm{m}^{-2} \mathrm{yr}^{-1}$ respectively). Second, remineralisation of non-recalcitrant allochthonous and autochthonous organic carbon is not only confined to the first year or so of surface deposition. Evidence suggests that mineralisation continues over the decades and even a century in a significant and measurable manner (Chuan et al. 2020; Gälman et al. 2008; Maher et al. 2017; Zimmerman \& Canuel 2002). The consequences are Threefold. First, respiration from the sediment community continues to erode the impact of annual NEP as a carbon sink over climatic scales. Second, before accumulation can be calculated, organic carbon concentrations will need to be corrected for losses to mineralisation after 100 years of deposition (Chuan et al. 2020). Third, while not conceptual, there are also 
considerations of applying best practices to determine accurate sedimentation rates from a ${ }^{210} \mathrm{~Pb}$ geochronology. These applications have several built-in assumptions for both their mapping methodologies and inductive models (Abril 2014). However, these are not always or sufficiently addressed within blue carbon research (Johannessen \& Macdonald 2016) through evaluation with one or a number of independent markers (Smith 2001). AS a consequence, untested overestimates can arise from neglecting the effects of surface mixing/bioturbation of deeper older deposits (Johannessen \& Macdonald 2016). Although for practical purposes, this is only when the ${ }^{210} \mathrm{~Pb}$ inventory of the surface mixed layer is $>15 \%$ of the columns' total (Lu \& Matsumoto 2005), a calculation that does is not always carried out. Not accounting for the loss of the sedimentary record due to erosion or massive deposition events (e.g, floods, storms or tsunamis) will obfuscate natural radioactive decay depth variance and give erroneous results (Gallagher and Ross 2017). Nevertheless, scenario analysis suggested that the average sedimentation rate within a dynamic blue carbon ecosystem may be sufficiently robust from a shortened $l n$-linear portion of a complex ${ }^{210} \mathrm{~Pb}$ decay profile, as determined by eye (Arias-Ortiz et al. 2018). Whether that approach is justified in the field (Gallagher and Ross 2017), the averaged sediment accumulation rate cannot capture variability, a prerequisite for carbon accreditation (Needelman et al. 2018).

\section{Is sequestration carbon accumulation?}

The issues of $N E P$ as sequestration relative to organic carbon accumulation and continued remineralisation are expanded and formalised with the use of three hypothetical scenarios (Fig. 1). Case I, II, and III develop from a simple closed immature system to a more complex mature open system. Whereupon use the use of uncorrected carbon accumulation becomes increasingly divergent from NEP. A means is then discussed on how to obtain the required additional information contained within the sedimentary record with a robust decomposition model. 
(a)
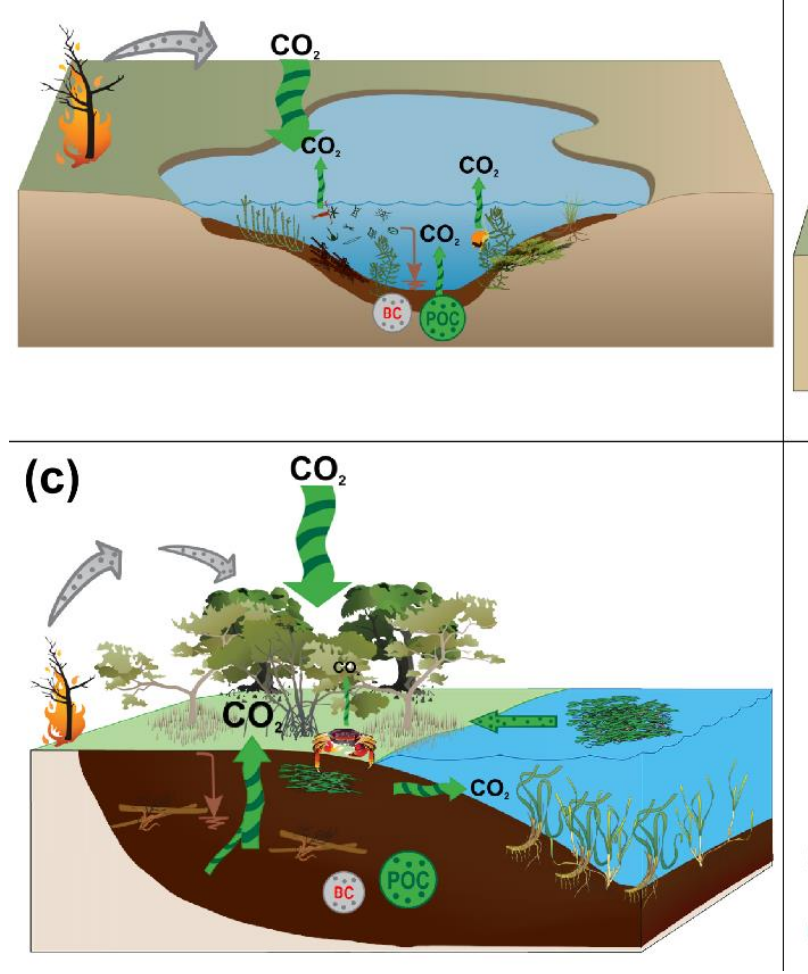

(b)

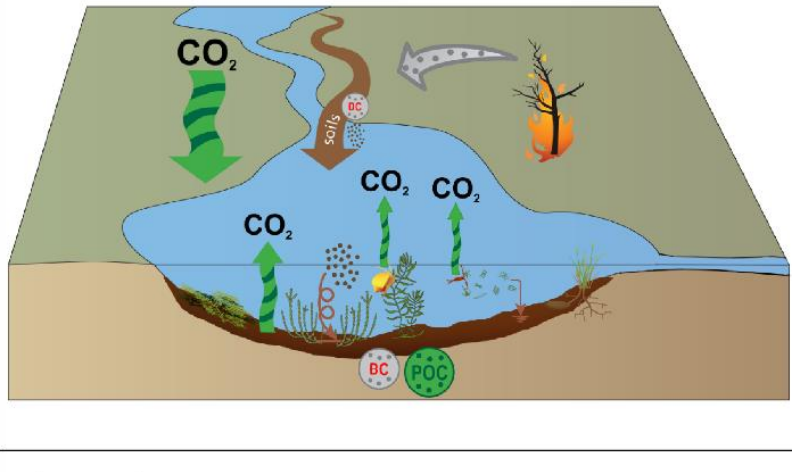

Legend

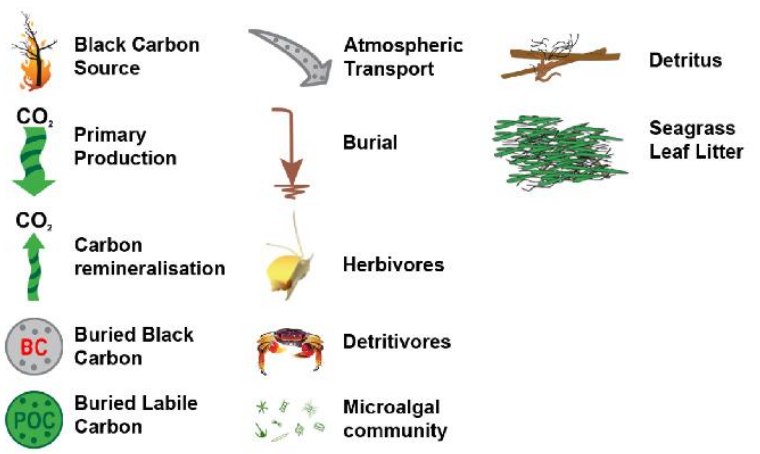

Fig. 1 Conceptual models for 'a' Case I; an immature subaquatic wetland pond after one year of deposition and closed to inputs and outputs but impacted by atmospheric deposition of black carbon; 'b' Case II; an immature aquatic wetland after one year of deposition, open to river and atmospheric inputs, and outputs; 'c' Case III; a mature intertidal mangrove with more than 100 years of deposits and open to atmospheric inputs, litter deposits from an adjacent seagrass ecosystem, with net losses of $\mathrm{CO}_{2}$ from the canopy from shallow and deep parts of the sediment column vertically, and laterally during tidal exchange. The figure was produced in Abode Illustrator CS6 $^{\mathrm{TM}}$ with components taken from Media Library Integration and Application Network (https://ian.umces.edu/media-library/).

\section{Case I: An immature closed wetland.}

This type of ecosystem approximates the beginning of an established closed wetland pond, or perhaps the start of restoration (Fig. 1a). This scenario was also set out by Prairie (Prairie et al. 2018) but modified here, as after one further year of deposition. Primary production and consumption are at a steady-state and confined within the wetland. The resultant $N E P$ then becomes the difference between the annual $\mathrm{CO}_{2}$ drawdown as it is fixed by the autotrophic assemblage $(G P P)$ over the amount respired, as it is consumed by the autotrophic assemblage $(P r)$ and the heterotrophic community. The community is composed of herbivores $(\mathrm{Hr})$, benthic detritivores $(\mathrm{Dr})$, and decomposers largely confined to sedimentary micro-flora $(\mathrm{Br})$. Once organic matter is deposited within the 
sediments, the microflora continues to consume and remineralise the remaining labile fraction leftover from detritivores over the following year (Cebrian 1999). Thus, the net rate of the remaining carbon accumulated within the sediments after 1 year of deposition is equivalent to the annual NEP for that previous year (Eq. 2). Under these conditions, carbon accumulation does indeed appear to be a proxy for NEP.

$N E P=G P P-P r-H r-D r-\int_{1 y}^{0 y} B r=C A a u t l$

\section{Case II: An immature open wetland.}

Most teal and blue carbon ecosystems are not isolated (Fig. 1b). Allochthonous organic carbon is added to wetlands either constantly or sporadically. For freshwater wetlands, this can come from rivers as components of soil and plant debris. On the other hand for coastal wetlands, adjacent seagrass, salt marsh, and mangroves can also supply material (Chuan et al. 2020; Gonneea et al. 2004). However, recalcitrant BC delivery can be from both soil washout and aerial deposition (Chew \& Gallagher 2018). Importantly, unlike a wetlands' innate primary production, labile allochthonous carbon has been fixed outside as a separate ecosystem service. Consequently, the effect on the NEP is then constrained by the amount of labile allochthonous carbon remineralised (Ir) within the ecosystem and not added to the carbon balance (Eq. 3). In other words, only the remineralisation of labile allochthonous production is an ecosystem service of receiving ecosystem, and not its production. This error appears to have been propagated from the terrestrial assessments, where allochthonous inputs rates were included in the NEP term to describe carbon accumulation (Lovett et al. 2006). Assuming most of the allochthonous inputs are rapidly deposited by the canopy into the surface sediments (Bos et al. 2007), their remineralisation is most likely confined within those sediments. The NEP then becomes the subtraction of the allochthonous remineralisation term from the autochthonous deposition term. This in turn can be estimated from the remains of the autochthonous and allochthonous carbon accumulated, from the deposition rate of allochthonous organic carbon to the sediments $(I)$ from what remains after one year $\left(I l_{l y}\right)($ Eq. 3).

$N E P=G P P-P r-H r-D r-\int_{1 y}^{0 y} B r-\int_{1 y}^{0 y} I r=$ CAaut $_{1 y}-\left(I-I l_{1 y}\right)$

Eq. 3 Where $I r$ is the fraction of the input of the allochthonous carbon $(I)$ that has been consumed and respired; I, is the rate of labile allochthonous supply of detritus to the ecosystem, and $I l_{1 y}$ the remains of that supply after a year of sediment decomposition, and $C_{\text {a autl }}$ is the accumulation of the remaining organic carbon produced within the ecosystem after a year of sediment decomposition.

$C A_{1 y}=\operatorname{CAautl}_{1 y}+I l_{1 y}$ 
By subtracting Eq. 4, the elements of carbon accumulation from the sedimentary and input terms in Eq. 3, show that the total organic carbon accumulation will overestimate $N E P$ by the rate by which allochthonous organic carbon is initially supplied to the sediments (Eq. 5). To state it in another way, the fraction of allochthonous carbon that has been decomposed is built into the amount remaining for accumulation. For example, should the allochthonous fraction be composed only of recalcitrant $\mathrm{BC}$, then $I l=B C$. Consequently, $N E P$ can be calculated by subtracting the sedimentary $\mathrm{BC}$ fraction from the total organic carbon accumulation rate, because $\mathrm{BC}$ is not consumed.

$N E P=C A_{1 y}-I I_{0 y}-B C$

\section{Case III: A mature intertidal wetland.}

Most canopy ecosystems are both open and have been sufficiently established to deposit an extensive sediment column (Fig. 1c). The depth of age of the column produces a legacy of sedimentary organic decay over the past century, albeit faster over decades, thus, further constraining Eq. 3 (Eq. 6). Indeed, for mangroves, it has been found that the mineralisation from century-old carbon deposits is tidally advected into adjacent waters at a rate equivalent to the $\mathrm{CO}_{2}$ vertical flux (Maher et al. 2018).

$N E P=N P P-H r-D r-\int_{100 y}^{0 y} B r-\int_{100 y}^{0 y r} I r=C_{A a u t} l_{100 y}-\left(I_{0 y}-I l_{100 y}\right)$

Eq. $6 N P P$ is the net primary production of the autotrophic assemblage $(G P P-P r)$ and $C A_{100 y}$ is the carbon accumulation as estimated from what remains after 100 years of decomposition.

By substituting (5), after correcting for remineralisation over climatic scales (100 years), into Eq. 6 and subtracting the allochthonous recalcitrants inputs such as $\mathrm{BC}\left(C A_{B C}\right)$, the $N E P$ becomes the difference between accumulated organic carbon after it has been deposited for 100 years $\left(C A_{100 y}\right)$ from the sum of the initial deposition rate for allochthonous carbon before consumption $\left(I_{0 y}\right)$, and the accumulation of allochthonous recalcitrants likely dominated by BC (Eq. 7).

$N E P=C A_{100 y}-\left(I_{0 y}+C A_{B C}\right)$

Surface horizons will thus require substantial corrections in the amount of carbon lost after 100 years of deposition, decreasing as the horizons become older. The true rate of mitigation through accumulation then becomes the product of the accretion rate and remaining concentrations after 100 years since it was deposited. Furthermore, the variability and trends for $N E P$ can be extracted throughout the sediment column irrespective of the degree of mineralisation or lateral exchange. 


\section{Is there a mitigation role for total organic carbon accumulation?}

The concept of locking away the remains of organic carbon produced and supplied to the ecosystem within the sediments still 'feels' like a sequestration concept. That is true, but only in the sense of what would have not been locked away if the canopy ecosystem had not been there. Some insights into the differences imposed by the presence of a canopy may be gauged from the population organic CA medians between vegetated and nonvegetated ecosystems- $62 \%$ of coastal wetland accumulation rates (Wilkinson et al. 2018). However, this comparison may need to be tempered as non-vegetated ecosystems will support a different mix of allochthonous and autochthonous carbon sources (Macreadie et al. 2014). Nevertheless, in some situations annual $C A$ may still provide additional information on ecosystem form or function. A larger $C A$ rate can separate a near equivalent $I r$ term between an ecosystem assemblage supplied by large amounts of relatively recalcitrant allochthonous carbon from another supplied by smaller amounts of more labile allochthonous carbon. Likewise, is also conceivable that they can also support similar standing stocks, should the larger amount of inorganic mineral material be associated with the supply of the more recalcitrant allochthonous sources. Wether annual $C A$ can be as a conditional vector stock service, perhaps another vector as a useful descriptor of the position of the wetland and various replacement scenario in mitigation 3D phase space with NEP and vulnerable stock servoice is an avenue of further discussion and testing.

\section{Putting it all together}

Taking into account carbon accumulation, it is proposed that the full value in preserving a wetland carbon sink can now be expressed by (Eq. 8).

$$
\text { Annual } C \text { off set credit }=(N E P-N E P R)+\frac{\theta}{\varphi}\left(\operatorname{Cstock}_{1 m}^{y=1}-T B C\right)+\left(\theta C A_{y=1}-C A_{B C}\right)
$$

Eq. 8 The components required for ecosystem carbon accreditation, relative to the replacement ecosystem. The net ecosystem production as calculated down the sedimentary record overtime for the canopy system $(N E P)$ and its replacement $(N E P R)(7) ; \operatorname{Cstock}_{1 \mathrm{~m}}^{y=1}$ the organic carbon stock down the sediment column, corrected for any decomposition after one year of deposition; $\theta$ the fraction of organic carbon vulnerable to remineralisation with its denominator $\varphi$ the time over which the vulnerable fraction was remineralised after disturbance to give the equation dimensional integrity with sequestration. In other words, the term is equivalent to the difference in what remains over the time it takes to establish its anthropogenic replacement towards a steady-state equilibrium. The term $\theta C A_{y=1}$ represents the vulnerable fraction of organic carbon stock accumulation after the decomposition of 
one year of wetland net annual production; and $T B C$ and $B C$ are the respective total (i.e. autochthonous and allochthonous) and allochthonous recalcitrant contributions, as represented by $B C$.

The carbon mitigation service of a restored wetland, however, is less than its preservation. The loss of stocks results in remineralisation of $\mathrm{CO}_{2}$ back to the atmosphere. Whereas, the accumulated increase in sediment stocks (i.e. $C A$ ) is an expression of the accumulation of autochthonous material over the consumption of its labile allochthonous fractions (Eq. 5). In other words, a restoration service is the measure of only the difference between the NEPR of the previous anthropogenic state and the NEP of a restored version to its natural state.

The above process would seem at a first inspection to be less than parsimonious. However, the apparent complexity only arises from the number of arithmetic operations. Notwithstanding accurate geochronologies, in the final analysis, accuracy only requires a robust sedimentary decomposition model for the different sources of organic carbon and a means to estimate the fractions of the autochthonous and allochthonous labile and recalcitrant sources. The model being used to both project remineralisation and hindcast allochthonous remains to the original concentration and inputs rates $\left(I_{0 y}\right)$ (Fig. 2a). For many programs, accurate geochronology and determination of organic sources are part of a best practice (Bindoff et al. 2019). To be useful, however, the decomposition model must account for or dismiss confounding differences in sediment types, redox conditions, temperatures, and organic sources across all time scales. This describes the relative precise and robust power model of Middelberg (1989) $(r=0.987)$, and its application by Zimmerman and Canuel (2002) to a mixed organic estuarine sediment column. The model describes how the organic mix becomes increasingly recalcitrant over time. The only requirement is a starting point for a continuously recalcitrant first-order decay constant characteristic of the organic mixture, or its organic components (Gallagher 2015). An alternative relies on a collection of cores (>20) sufficient to normalise models for variability in space as a proxy for time (Strayer et al. 1986; Johannessen et al., 2021), or identifying asymptote concentrations with depth. However, the former is resource-intensive and requires a gradient of sedimentation and source supply rates. For the latter, simple decay to an asymptote with depth requires a constant rate of deposition and unchanging proportions of all organic sources. This is not usual for canopy ecosystems. Concentration profiles are often characterised by a series of complex broad peaks and troughs, and in many cases, surface concentrations are less than their centennial counterparts (Callaway et al. 2012; Ellison \& Beasy 2018; Gonneea et al. 2004; Rozaimi Jamaludin et al. 2017; Serrano et al. 2014). 

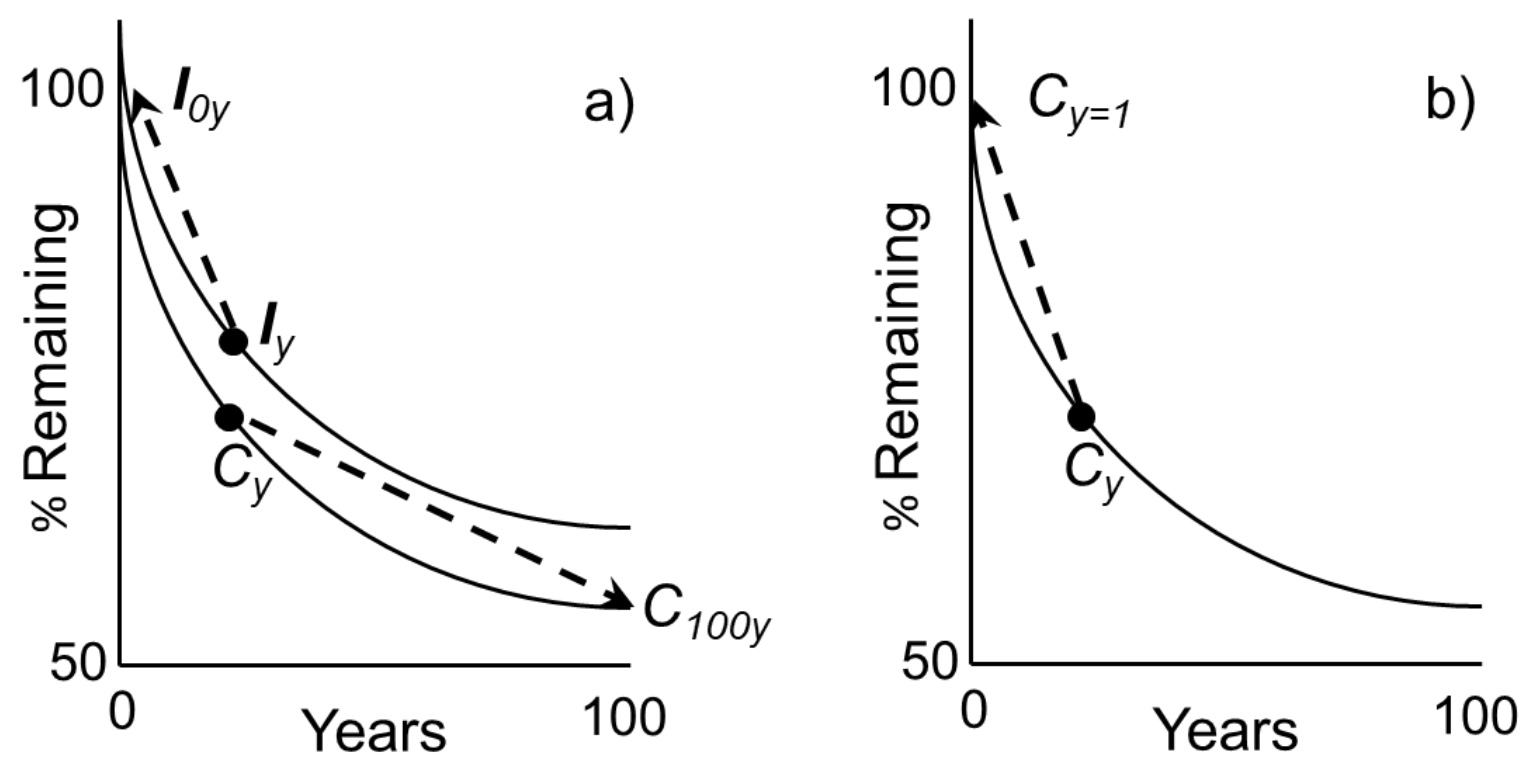

Fig. 2 Hypothetical sedimentary decomposition curves required to estimate NEP and carbon accumulation at climatic time scales. Curves within ' $a$ ' illustrate the process used to estimate the NEP (Eq. 5) from carbon accumulation rates, after correcting the component's sedimentary content over times of deposition. The allochthonous content $I_{y}$ sits on its remineralisation curve as an example of a relatively recalcitrant form. It represents what remains after ' $y$ ' years of deposition from its original content $I_{0 y}$ deposited and mixed into the surface sediment layer. The total organic carbon content mixture $\left(C_{y}\right)$ sits on a relatively labile remineralisation curve as the sum of individual organic components decomposition curves, weighted for their respective fractions. It represents what remains after ' $y$ ' years of deposition and projected to what would remain over climatic time scales ( i.e. 100 years). Curve 'b' represents the used to hindcast an example of the content $C y$ to the time of the original annual deposition $C_{y}=1$ (see section “Is there a mitigation role for total organic carbon accumulation?"). The figure was drawn within Microsoft PowerPoint ${ }^{\mathrm{TM}} 2013$.

\section{Testing the accreditation model}

Two examples were chosen from the available literature to calculate the annual NEP variability over decadal to centennial time scales as determined from (Eq. 7). A mangrove sediment containing moderately labile seagrass litter (Gonneea et al. 2004), using BC estimates from similar systems. A seagrass sediment dominated by relatively recalcitrant mangrove detritus and moderate fractions of BC (Chuan et al. 2020). Full details of the site descriptions, the diagenetic models, for $N E P$ estimates and the evaluation are found in Supplementary Information (S1). Data sets within templates for the decomposition decay curves used for the hindcasting and projection of 
variables (Eq. 7), stability tests, first-order component decay parameters, and the evaluation, can be found as Excel $^{\mathrm{TM}}$ files Supplementary Information (S2) and (S3), along with embedded instructions (https://doi.org/10.25959/NNHB-T463). Details and support behind the theory can be found in Supplementary Information (S1).

\section{Results of case studies}

\section{Net ecosystem production and carbon accumulation}

The sediment accumulation rates were an order of magnitude higher in the mangrove forest than in the seagrass meadow (Fig. 3a, b). There was a considerable disparity between total organic carbon accumulation rates and the calculated NEP for both systems. For the mangrove forest, the median $C A$ rate was over 33.5 times greater than $N E P$. This was not much less than $C A$ rates after correction for decomposition losses $(27.5 \mathrm{x})$ (Fig. 3a). This relative difference, however, was reduced for their respective median NEP rates. The seagrass meadow NEP (7.2 $\left.\mathrm{gC} \mathrm{m}^{-2} \mathrm{yr}^{-1}\right)$ was around 4 times less than the mangrove forest $N E P\left(27.6 \mathrm{gC} \mathrm{m}^{-2} \mathrm{yr}^{-1}\right)$ (Fig. 3a, b). Indeed, from the limited data available, it appears that the seagrass had been essentially carbon-neutral over the last 15 years (geometric mean $=0 \mathrm{gC} \mathrm{m}^{-2} \mathrm{yr}^{-1}$ ). For the seagrass meadow, this likely reflects a respiration assault from the consumption of high rates of supply of relatively labile allochthonous mangrove litter $(75.4 \%$ to $80.4 \%$ of organic carbon, Supplementary Information (S3)). However, the differences for the mangrove reflect the smaller allochthonous supply of a more labile phytoplankton assemblage.
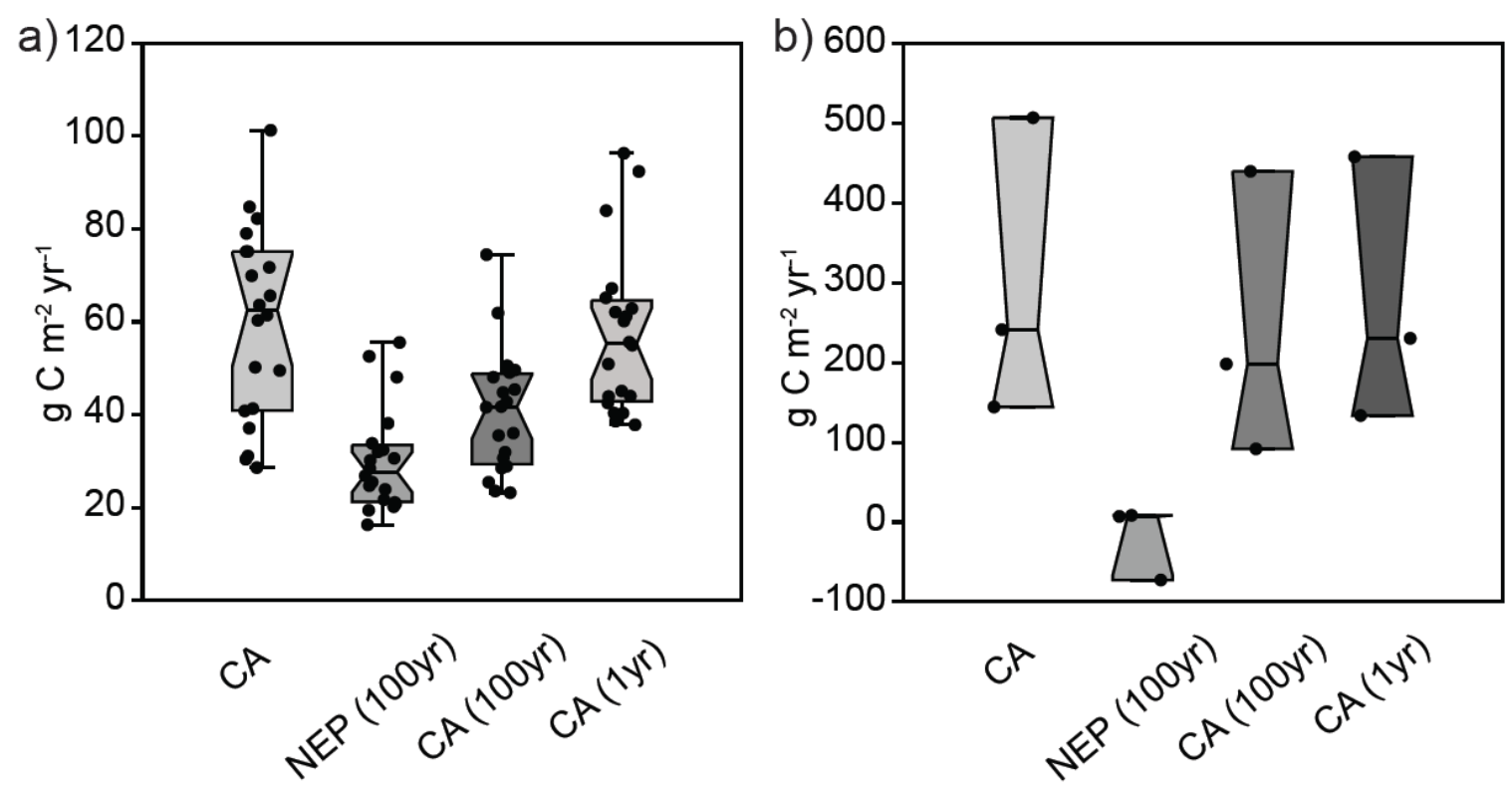

Fig. 3 Carbon sink concepts estimated down the sedimentary record for 'a' the seagrass meadow at Salut lagoon; and ' $b$ ' the mangrove forest at Chelem lagoon. The points $(0)$ represent $C A$ concepts at different depositional ages down their respective sediment columns (see Supplementary Information (S3)). The net ecosystem 
production after 100 years of deposition (NEP(100yrs)); Sediment carbon accumulation after 100 years of deposition (CA (100yr)) and without decomposition corrections (CA); 62\% of carbon stock accumulation hindcasted to one year of accumulation $(\mathrm{CA}(1 \mathrm{yr}))$ if hypothetically it was deposited within a non-vegetated patch (see section "Is there a mitigation role for total organic carbon accumulation?"). The figure was created in the statistical software package PAST $^{\mathrm{TM}}$, exported as a svg file then modified and converted to an eps file within Abode Illustrator CS6 ${ }^{\mathrm{TM}}$.

Interestingly, the overall variability seen in $C A$ rates was notably less than the relative variability in their respective $N E P$ (Fig. 3a, b). Unlike the mangrove forest, the seagrass meadows' NEP switched between heterotrophy (-72.5 $\left.\mathrm{gC} \mathrm{m}^{-2} \mathrm{yr}^{-1}\right)$ and autotrophy $\left(7.2\right.$ and $\left.8.5 \mathrm{gC} \mathrm{m}^{-2} \mathrm{yr}^{-1}\right)$. These values are within the range reported from direct measurements also across a lagoon system (-92 to $227 \mathrm{gC} \mathrm{m}^{-2} \mathrm{yr}^{-1}$ ) for the boreal region, and their shallow subtropical counterparts immediately outside a lagoon (-539 to $\left.215 \mathrm{gC} \mathrm{m}^{-2} \mathrm{yr}^{-1}\right)$ (Tokoro et al. 2014). For the mangrove forest, the NEP maintained a degree of autotrophy through the century of deposition, ranging from 16.3 to $55.5 \mathrm{gC} \mathrm{m}^{-2} \mathrm{yr}^{-1}$ (median $26.9 \mathrm{gC} \mathrm{m}^{-2} \mathrm{yr}^{-1}$ ). This median and range are notably smaller than reported for global medians of between $628 \mathrm{gC} \mathrm{m}^{-2} \mathrm{yr}^{-1}$ (Alongi 2020) and $221 \mathrm{gC} \mathrm{m}^{-2} \mathrm{yr}^{-1}$ (Duarte et al. 2005). However, the estimates were largely based on measurements of gas emissions emanating from the canopy system and could account for the significant lateral transport of remineralisation products during tidal exchange from the deeper parts of the sediment column (Fig. 1d) (Maher et al. 2018). Nevertheless, the examples suggest that $C A$ augmented with allochthonous inputs would likely lead to major overestimates of sequestration, irrespective of decompositional corrections (Fig. 3). However, this hierarchy could conceivably be reversed during the early to mid-stages of a restoration. Stocks would not have had sufficient time to accumulate and the canopy and root system may not have been sufficiently developed to fully promote carbon accumulation.

\section{Carbon accredited offsets, stocks, and sequestration}

Current methodology for wetland carbon mitigation offsets is determined from the difference in vulnerable carbon stocks between its baseline or replacement ecosystem as the time it takes for the baseline to establish itself towards a steady-state equilibrium (Needelman et al. 2018). For seagrass and mangroves, this was calculated as typically 732 and $636 \mathrm{gC} \mathrm{m}^{-2} \mathrm{yr}^{-1}$ respectively. This assumed that the sedimentary standing stock today is a good representative of the last century median (Supplementary Information (S1)), and losses to remineralisation were on average around 75\% (Pendleton et al. 2011) as the anthropogenic replacement established itself over the next 20 years. In addition, corrections for recalcitrants were made as an allochthonous BC fraction, measured at $11 \%$ for the seagrass and estimated at $5 \%$ for the mangrove (Supplementary Information (S1)). Although it should be 
noted for salt marsh and coastal seagrass meadows, BC fractions can reach as high as a third and close to half of their carbon stocks and respectively (Gallagher et al. 2021a). However, we did not include the suggested additional prospective stock vector, which describes the annual carbon accumulation without a canopy service to otherwise increase net deposition rates. Whether its addition is justified will depend on its ability to separate form and function within similar wetland categories; a classification system yet as not explored or its need tested.

Along with stocks, it has been argued that sequestration, as its annual NEP is required to assess the wetlands' full mitigation potential (Eq. 8) relative to its anthropogenic replacement. For comparison with the mangrove system, Jobo Bay was chosen (Caffrey et al. 2004) as typical for the seagrass replacement The bay occupies a similar niche of tropical enclosed embayment supporting a non-vegetated bottom surrounded by fringing mangroves. For the mangrove, the annual average NEP of mangrove shrimp aquaculture ponds was chosen as its anthropogenic replacement (Chen et al. 2016).

Seagrass preservation $\quad+1921.2 \mathrm{gC} \mathrm{m}^{-2} \mathrm{yr}^{-1}=\left(+7.2 N E P_{\text {seagrass }}-\left(-450 N E P_{\text {baseline }}\right)\right)+732 C_{\text {stock }}$

Mangrove preservation $\quad+690.6 \mathrm{gC} \mathrm{m}^{-2} \mathrm{yr}^{-1}=\left(+27.6 N E P_{\text {seagrass }}-\left(+5 N E P_{\text {baseline }}\right)\right)+668 C_{\text {stock }}$

Interestingly, while the sum of stock and individual $N E P$ services stocks converge, what ultimately determines the differences appears to be the NEP of their anthropogenic replacements (Eqs. 9, 10). Although, one may have to consider that the anthropogenic replacement may support a larger $N E P$ rate and reduce the overall accreditation service. This would be the case for mangroves replacing salt marsh (Alongi 2020) and conceivably for the above seagrass example should it's the supply of mangrove detritus be lost from shoreline developments. The calculation also highlights, indirectly, the importance of neglecting the potential fate of a considerable stock house within mangrove trees and root biomass. No information is available for this mangroves' biomass. Nevertheless, a mangrove biomass for a similar niche and species assemblage close to the entrance of its lagoon (Gallagher et al. 2020), suggests an additional mitigation service of around $891 \mathrm{gC} \mathrm{m}^{-2} \mathrm{yr}^{-1}$, should the mangrove be consumed or burnt over 20 years. This is in contrast to the largely insignificant contribution of seagrass biomass to relative its meadows' total organic carbon stock (Gallagher et al. 2020). Together, there appears to be a surprising convergence between the mitigation potential of these two disparate tropical ecosystems (i.e. $1581.6 \mathrm{gC} \mathrm{m}^{-2} \mathrm{yr}^{-1}$ and $1923.4 \mathrm{gC} \mathrm{m}^{-2} \mathrm{yr}^{-1}$ for the mangrove and seagrass respectively). Although, it must be said that the convergence was enhanced by the relative positions within their lagoons. The mangrove forest is located close to the entrance where carbon biomass is just over half of the upper lagoon counterparts (Gallagher et al. 2020). In contrast, the seagrass meadow is located in the upper and muddier parts of its lagoon, where sedimentary carbon stock is more than 10 greater than their lower lagoon counterparts (Gallagher et al. 2020). Either way, the significant fraction 
as stocks (Eqs 9 and 10) for both systems suggests that restoration is likely to be around a third less valuable than preservation as a mitigation service.

\section{Conclusions}

A full carbon accrediting assessment for the preservation of wetlands requires estimates of both sequestration and only stocks that are vulnerable to remineralisation relative to their anthropogenic replacements. However, only relative sequestration need only be considered for wetland restoration. continued remineralisation of the annual deposition of sedimentary organic stocks suggests that any estimate of sequestration should be calculated over climatic scales. This is after significant fractions of allochthonous recalcitrants such as black carbon are subtracted from that service. However, total $C A$ is not a measure of sequestration, as previously used to account for centennial variability, for it will significantly overestimate this service, be it uncorrected or corrected for continued remineralisation. Nevertheless, with the use of a robust decomposition model and a means to untangle organic source contributions, the sedimentary record contains sufficient information to determine reasonable estimates of sequestration as the NEP. The review shows that conceptually unbiased and complete measurements of mitigation services will assure i) confidence across both voluntary and compliance carbon markets in that $G H G$ offsets do not permit emissions above the capacity of a wetland; ii) underestimate the ability for regions to reach zero net carbon emission targets.

\section{Acknowledgments}

We thank Dr Meagan Eagle Gonneea for providing the data required for the mangrove case study, associated with her published paper, and to Dr Sophia C Johannessen for her comments on the manuscript. 


\section{Declarations}

\section{Funding sources}

No funding was provided.

\section{Conflict of interest/competing interests}

The authors declare that they have no known competing financial interests or personal relationships that could have appeared to influence the work reported in this paper.

\section{Ethics approval}

Not applicable, no animal or plant materials were disturbed or manipulated during sampling or analysis

Guidelines on ethical review or waiver

Australia: https://www.arc.gov.au/policies-strategies/policy/codes-and-guidelines (accessed November 2021).

\section{Consent to participate}

Not applicable.

\section{Consent for publication}

Not applicable.

\section{Availability of data and material.}

Supplementary Information (S3) and (S4) and

\section{CRediT authorship contribution statement}

JBG: Conceptualization, Validation, Formal analysis, Investigation, Writing - original draft, Writing - review \& editing, Visualization, KZ: Conceptualization Writing - review \& editing, CHC: Validation, Visualization, Writing - review \& editing. All authors read and approved the final manuscript. 


\section{References}

Abril JM (2004) Constraints on the use of ${ }^{137}$ Cs as a time-marker to support CRS and SIT chronologies. Environmental Pollution 129(1): 31-37. https://doi.org/10.1016/j.envpol.2003.10.004

Alongi DM (2020) Carbon Balance in Salt Marsh and Mangrove Ecosystems: A Global Synthesis. Journal of Marine Science and Engineering 8(10): 767. https://doi.org/10.3390/jmse8100767

Arias-Ortiz A, Masqué P, Garcia-Orellana J, Serrano O, Mazarrasa I, Marbà N, Lovelock CE, Lavery PS, Duarte CM (2018) Reviews and syntheses: 210Pb-derived sediment and carbon accumulation rates in vegetated coastal ecosystems - setting the record straight. Biogeosciences 15(22): 6791-6818. https://doi.org/10.5194/bg-15-67912018

Bellon-Maurel V, McBratney A (2011) Review: Near-infrared (NIR) and mid-infrared (MIR) spectroscopic techniques for assessing the amount of carbon stock in soils - Critical review and research perspectives. Soil Biology and Biochemistry 43: 1398-1410. https://doi.org/10.1016/j.soilbio.2011.02.019

Bindoff NL, Cheung WWL, Kairo JG, Arístegui J, Guinder VA, R. Hallberg, N. Hilmi, N. Jiao, Karim MS, Levin L, O’Donoghue S, Purca Cuicapusa SR, Rinkevich B, Suga T, Tagliabue A, P. W (2019) Changing Ocean, Marine Ecosystems, and Dependent Communities. In: Pörtner HO, Roberts DC, Masson-Delmotte V, Zhai P, Tignor M, Poloczanska E, Mintenbeck K, Alegría A, Nicolai M, Okem A, Petzold J, Rama B \& M. WN (eds) In: IPCC Special Report on the Ocean and Cryosphere in a Changing Climate.

Bos AR, Bouma TJ, de Kort GLJ, van Katwijk MM (2007) Ecosystem engineering by annual intertidal seagrass beds: Sediment accretion and modification. Estuarine, Coastal and Shelf Science 74(1-2): 344-348. http://dx.doi.org/10.1016/j.ecss.2007.04.006

Burdige DJ (2007) Preservation of organic matter in marine sediments: Controls, mechanisms, and an imbalance in sediment organic carbon budgets? Chemical Reviews 107(2): 467-485. https://doi.org/10.1021/cr050347q Byers SC, Mills EL, Stewart PL (1978) A comparison of methods of determining organic carbon in marine sediments, with suggestions for a standard method. Hydrobiologia 58(1): 43-47. https://doi.org/10.1007/BF00018894

Cabanes D, Weiner S, Shahack-Gross R (2011) Stability of phytoliths in the archaeological record: a dissolution study of modern and fossil phytoliths. Journal of Archaeological Science 38(9): 2480-2490. https://doi.org/10.1016/j.jas.2011.05.020

Caffrey JM. (2004). Factors controlling net ecosystem metabolism in U.S. estuaries. Estuaries, 27: 90-101. https:/doi.org/10.1007/bf02803563 
Callaway JC, Borgnis EL, Turner RE, Milan CS (2012) Carbon Sequestration and Sediment Accretion in San Francisco Bay Tidal Wetlands. Estuaries and Coasts 35(5): 1163-1181. https://doi.org/10.1007/s12237-012-95089

Carnell PE, Windecker SM, Brenker M, Baldock J, Masque P, Brunt K, Macreadie PI (2018) Carbon stocks, sequestration, and emissions of wetlands in South Eastern Australia. Global Change Biology 24(9): 4173-4184. https://doi.org/10.1111/gcb.14319

Cary L, Alexandre A, Meunier J-D, Boeglin J-L, Braun J-J (2005) Contribution of phytoliths to the suspended load of biogenic silica in the Nyong basin rivers (Cameroon). Biogeochemistry 74(1): 101-114. https://doi.org/10.1007/s10533-004-2945-1

Cathalot C, Rabouille C, Tisnérat-Laborde N, Toussaint F, Philippe K, Buscail R, Loftis K, M-Y S, Tronczyński JSA, Lansard B, Treignier C, Pastor L, Tesi T (2013) The fate of river organic carbon in coastal areas: A study in the Rhône River delta using multiple isotopic $(\delta 13 \mathrm{C}, \Delta 14 \mathrm{C})$ and organic tracers. Geochimica et Cosmochimica Acta 118: 33-55. https://doi.org/10.1016/j.gca.2013.05.001

Cebrian J (1999) Patterns in the fate of production in plant communities. The American Naturalist 154(4): 449468. https://do.org/10.1086/303244

Cebrian J (2002) Variability and control of carbon consumption, export, and accumulation in marine communities. Limnology and Oceanography 47(1): 11-22. https://doi.org/10.4319/lo.2002.47.1.0011

Chapin FS, Woodwell GM, Randerson JT, Rastetter EB, Lovett GM, Baldocchi DD, Clark DA, Harmon ME, Schimel DS, Valentini R, Wirth C, Aber JD, Cole JJ, Goulden ML, Harden JW, Heimann M, Howarth RW, Matson PA, McGuire AD, Melillo JM, Mooney HA, Neff JC, Houghton RA, Pace ML, Ryan MG, Running SW, Sala OE, Schlesinger WH, Schulze ED (2006) Reconciling Carbon-cycle Concepts, Terminology, and Methods. Ecosystems 9(7): 1041-1050. https://doi.org/10.1007/s10021-005-0105-7

Chen Y, Dong S, Wang F, Gao Q, Tian X (2016) Carbon dioxide and methane fluxes from feeding and no-feeding mariculture ponds. Environmental Pollution, 212: 489-497. https://doi.org/10.1016/j.envpol.2016.02.039

Chew ST, Gallagher JB (2018) Accounting for black carbon lowers estimates of blue carbon storage services. Sci Rep 8(1): 2553. https://doi.org/10.1038/s41598-018-20644-2

Chee SY, Othman AG, Sim YK, Mat Adam AN, Firth LB (2017) Land reclamation and artificial islands: Walking the tightrope between development and conservation. Global Ecology and Conservation, 12: 80-95. https://doi.org/10.1016/j.gecco.2017.08.005 
Chee, SY, Chai YJ, Carey D, Yusup Y, Gallagher, JB (2020) Anthropogenic marine debris and its dynamics across peri-urban and urban mangroves on Penang Island, Malaysia. Journal of Sustainability Science and Management, 15: 41-67.

Chmura GL (2013) What do we need to assess the sustainability of the tidal salt marsh carbon sink? Ocean \& Coastal Management 83: 25-31. https://doi.org/ 10.1016/j.ocecoaman.2011.09.006

Chuan CH, Gallagher JB, Chew ST, Norlaila Binti MZ (2020) Blue carbon sequestration dynamics within tropical seagrass sediments: long-term incubations for changes over climatic scales. Marine and Freshwater Research 71(8): 892-904. https://doi.org/10.1071/mf19119

Costanza R, Mageau M (1999) What is a healthy ecosystem? Aquatic Ecology 33(1): 105-115. https://doi.org/ 10.1023/a:1009930313242

Craft CB, Seneca ED, Broome SW (1991) Loss on Ignition and Kjeldahl Digestion for Estimating Organic Carbon and Total Nitrogen in Estuarine Marsh Soils: Calibration with Dry Combustion. Estuaries 14(2): 175. https://dx.doi.org/10.2307/1351691

de Paoli H, van der Heide T, van den Berg A, Silliman BR, Herman PMJ, van de Koppel J (2017) Behavioral selforganization underlies the resilience of a coastal ecosystem. Proceedings of the National Academy of Sciences 114(30): 8035-8040. https://doi.org/ 10.1073/pnas.1619203114

Duarte CM, Marbà N, Gacia E, Fourqurean JW, Beggins J, Barrón C, Apostolaki ET (2010) Seagrass community metabolism: Assessing the carbon sink capacity of seagrass meadows. Global Biogeochemical Cycles 24(4): GB4032. https://doi.org/10.1029/2010GB003793

Duarte CM, Middelburg JJ, Caraco N (2005) Major role of marine vegetation on the oceanic carbon cycle. Biogeosciences 2(1): 1-8. https://doi.org/10.5194/bg-2-1-2005

Duarte CM, Prairie YT (2005) Prevalence of Heterotrophy and Atmospheric CO2 Emissions from Aquatic Ecosystems. Ecosystems 8(7): 862-870. https://doi.org/10.1007/s10021-005-0177-4

Ellison J, Beasy K (2018) Sediment Carbon Accumulation in Southern Latitude Saltmarsh Communities of Tasmania, Australia. Biology 7(2): 27. https://doi.org/10.3390/biology7020027

Eong OJ (1993) Mangroves - a carbon source and sink. Chemosphere 27(6): 1097-1107. https://doi.org/10.1016/0045-6535(93)90070-L

Forbrich I, Giblin AE, Hopkinson CS (2018) Constraining Marsh Carbon Budgets Using Long-Term C Burial and Contemporary Atmospheric CO2 Fluxes. Journal of Geophysical Research: Biogeosciences 123(3): 867-878. https://doi.org/10.1002/2017jg004336 
Fourqurean JW, Duarte CM, Kennedy H, Marba N, Holmer M, Mateo MA, Apostolaki ET, Kendrick GA, KrauseJensen D, McGlathery KJ, Serrano O (2012) Seagrass ecosystems as a globally significant carbon stock. Nature Geoscience 5(7): 505-509. https://doi.org/10.1038/ngeo1477

Gallagher JB (2015) The implications of global climate change and aquaculture on blue carbon sequestration and storage within submerged aquatic ecosystems. In: Mustafa S \& Shapawi R (eds) Aquaculture Ecosystems. Wiley Blackwell, Oxford. p 243-280

Gallagher JB (2017) Taking stock of mangrove and seagrass blue carbon ecosystems: A perspective for future carbon trading. Borneo Journal of Marine Science and Aquaculture, 1: 71-74.

Gallagher JB, Chew ST, Madin J, Thorhaug A, (2020). Valuing Carbon Stocks across a Tropical Lagoon after Accounting for Black and Inorganic Carbon: Bulk Density Proxies for Monitoring. Journal of Coastal Research, 36: 1029-1039, 1011. https://doi.org/10.2112/JCOASTRES-D-19-00127.1

Gallagher JB, Chuan CH, Yap TK, Fredelina Dona WF (2019) Carbon stocks of coastal seagrass in Southeast Asia may be far lower than anticipated when accounting for black carbon. Biol Lett 15(5): 20180745. https://doi.org/10.1098/rsbl.2018.0745

Gallagher JB, Prahalad V, Aalders J (2021a) Inorganic and Black Carbon Hotspots Constrain Blue Carbon Mitigation Services Across Tropical Seagrass and Temperate Tidal Marshes. Wetlands 41(5): 65. https://doi.org/10.1007/s13157-021-01460-3

Gallagher JB, Shelamoff V, Layton C. (2021b) (Preprint). Missing the forest for the trees: Do seaweed ecosystems mitigate $\mathrm{CO}_{2}$ emissions? Cold Spring Harbor Laboratory. https://dx.doi.org/10.1101/2021.09.05.459038

Gallagher JB, Ross, DJ. 2017. Sediment geochronology for bar-built estuaries subject to flood deposition and erosion: A robust multiproxy approach across an estuarine zone. The Holocene, 28: 341-353. htpps://doi.org/10.1177/0959683617729441

Gälman V, Rydberg J, De-Luna SS, Bindler R, Renberg I (2008) Carbon and nitrogen loss rates during aging of lake sediment: Changes over 27 years studied in varved lake sediment. Limnology and Oceanography 53(3): 1076-1082. https://doi.org/10.4319/lo.2008.53.3.1076

Gonneea ME, Paytan A, Herrera-Silveira JA (2004) Tracing organic matter sources and carbon burial in mangrove sediments over the past 160 years. Estuarine, Coastal and Shelf Science 61(2): 211-227. https://doi.org/10.1016/j.ecss.2004.04.015 
Gruber RK, Lowe RJ, Falter JL (2017) Metabolism of a tide-dominated reef platform subject to extreme diel temperature and oxygen variations. Limnology and Oceanography 62(4): 1701-1717. https://doi.org/10.1002/lno.10527

Heiri O, Lotter AF, Lemcke G (2001) Loss on ignition as a method for estimating organic and carbonate content in sediments: reproducibility and comparability of results. Journal of Paleolimnology 25(1): 101-110. https://doi.org/10.1023/A:1008119611481

Hoegh-Guldberg O, Jacob D, Taylor M, Bindi M, Brown S, Camilloni I, Diedhiou A, Djalante R, Ebi K, Engelbrecht F, Zhou G, Joel G, Hijioka Y, Mehrotra S, Payne A, Seneviratne S, Thomas A, Warren R, Halim S, Guillén Bolaños T (2018) Chapter 3: Impacts of $1.5^{\circ} \mathrm{C}$ global warming on natural and human systems. In: Global Warming of $1.5^{\circ} \mathrm{C}$. An IPCC special report on the impacts of global warming of $1.5^{\circ} \mathrm{C}$ above preindustrial levels and related global greenhouse gas emission pathways [...]. In. p 175-311. https://www.ipcc.ch/sr15/

Howard JL, Creed JC, Aguiar MVP, Fourqurean JW (2018) CO2 released by carbonate sediment production in some coastal areas may offset the benefits of seagrass "Blue Carbon" storage. Limnology and Oceanography 63(1): 160-172. https://doi.org/10.1002/lno.10621

Hu Y, Fest BJ, Swearer SE, Arndt SK (2021) Fine-scale spatial variability in organic carbon in a temperate mangrove forest: Implications for estimating carbon stocks in blue carbon ecosystems. Estuarine, Coastal and Shelf Science 259: 107469. https://doi.org/10.1016/j.ecss.2021.107469

IPCC (2014) IPCC 2013 Supplement to the 2006 IPCC Guidelines for National Greenhouse Gas Inventories: Wetlands. In: Hiraishi T, Krug T, Tanabe K, Srivastava N, Baasansuren J, Fukuda M \& Troxler TG (eds). IPCC, Switzerland.

Järviö N, Henriksson PJG, Guinée JB (2018) Including GHG emissions from mangrove forests LULUC in LCA: a case study on shrimp farming in the Mekong Delta, Vietnam. The International Journal of Life Cycle Assessment 23(5): 1078-1090. https://doi.org/10.1007/s11367-017-1332-9

Jennerjahn TC (2020) Relevance and magnitude of 'Blue Carbon' storage in mangrove sediments: Carbon accumulation rates vs. stocks, sources vs. sinks. Estuarine, Coastal and Shelf Science 247: 107027. https://doi.org/10.1016/j.ecss.2020.107027

Johannessen SC, Macdonald RW (2016) Geoengineering with seagrasses: is credit due where credit is given? Environmental Research Letters 11(11): 113001. https://doi.org/10.1088/1748-9326/11/11/113001

Johannessen SC, Macdonald RW, Strivens JE (2021) Has primary production declined in the Salish Sea? Canadian Journal of Fisheries and Aquatic Sciences 78(3): 312-321. https://doi.org/10.1139/cjfas-2020-0115 
Kayranli B, Scholz M, Mustafa A, Hedmark Å (2010) Carbon Storage and Fluxes within Freshwater Wetlands: a Critical Review. Wetlands 30(1): 111-124. https://doi.org/10.1007/s13157-009-0003-4

Krause-Jensen, D., Lavery, P., Serrano, O., Marbà, N., Masque, P., and Duarte, C. M. 2018. Sequestration of macroalgal carbon: the elephant in the Blue Carbon room. Biology Letters, 14: 20180236. https://dx.doi.org/10.1098/rsbl.2018.0236

Lal R (2008) Carbon sequestration. Philosophical Transactions of the Royal Society B: Biological Sciences 363(1492): 815-830. https://doi.org/10.1098/rstb.2007.2185

Lavelle JW, Massoth GJ, Crecelius EA (1986) Accumulation rates of Recent sediments in Puget Sound, Washington. Marine Geology 72(1-2): 59-70. https://doi.org/10.1016/0025-3227(86)90099-x

Leorri E, Zimmerman AR, Mitra S, Christian RR, Fatela F, Mallinson DJ (2018) Refractory organic matter in coastal salt marshes-effect on C sequestration calculations. Sci Total Environ 633: 391-398. https:/doi.org/10.1016/j.scitotenv.2018.03.120

Lovett GM, Cole JJ, Pace ML (2006) Is Net Ecosystem Production Equal to Ecosystem Carbon Accumulation? Ecosystems 9(1): 152-155. https://doi.org/10.1007/s10021-005-0036-3

Lu W, Xiao J, Liu F, Zhang Y, Liu C, Lin G (2017) Contrasting ecosystem CO2 fluxes of inland and coastal wetlands: a meta-analysis of eddy covariance data. Glob Chang Biol 23(3): 1180-1198. https://doi.org/10.1111/gcb.13424

Lu X, Matsumoto E (2005) Recent sedimentation rates derived from 210Pb and 137Cs methods in Ise Bay, Japan. Estuarine, Coastal and Shelf Science 65(1-2): 83-93. https://doi.org/10.1016/j.ecss.2005.05.009

. B, Keith H, L. Berry S, B. Lindenmayer D (2008) Green Carbon: The role of natural forests in carbon storage. ANU Press

Macreadie PI, York PH, Sherman CDH, Keough MJ, Ross DJ, Ricart AM, Smith TM (2014) No detectable impact of small-scale disturbances on 'blue carbon' within seagrass beds. Marine Biology 161(12): 2939-2944. https://doi.org/10.1007/s00227-014-2558-8

Macreadie PI, Costa, MDP, Atwood TB, Friess DA, Kelleway, JJ, Kennedy ., Lovelock CE, et al.(2021) Blue carbon as a natural climate solution. Nature Reviews Earth \& Environment. https://doi.org/10.1038/s43017-02100224-1

Maher DT, Call M, Santos IR, Sanders CJ (2018) Beyond burial: lateral exchange is a significant atmospheric carbon sink in mangrove forests. Biology Letters 14(7). https://doi.org/10.1098/rsbl.2018.0200 
Maher DT, Santos IR, Schulz KG, Call M, Jacobsen GE, Sanders CJ (2017) Blue carbon oxidation revealed by radiogenic and stable isotopes in a mangrove system. Geophysical Research Letters 44(10): 4889-4896. https://doi.org/10.1002/2017GL073753

Maher DT, Eyre BD (2012) Carbon budgets for three autotrophic Australian estuaries: Implications for global estimates of the coastal air-water CO2 flux. Global Biogeochemical Cycles 26: Gb1032. https://doi.org/10.1029/2011gb004075

Marba N, Duarte CM (1997) Interannual changes in seagrass (Posidonia oceanica) growth and environmental change in the Spanish Mediterranean littoral zone. Limnology and Oceanography 42(5): 800-810. https://doi.org/10.4319/lo.1997.42.5.0800

McLeod E, Chmura, GL, Bouillon S, Salm R, Björk M, Duarte CM, Lovelock CE, et al. (2011) A blueprint for blue carbon: toward an improved understanding of the role of vegetated coastal habitats in sequestering $\mathrm{CO}_{2}$. Frontiers in Ecology and the Environment, 9: 552-560. https://doi.org/ 10.1890/110004

Mitsch WJ, Bernal B, Nahlik AM, Mander Ü, Zhang L, Anderson CJ, Jørgensen SE, Brix H (2013) Wetlands, carbon, and climate change. Landscape Ecology 28(4): 583-597. https://doi.org/10.1007/s10980-012-9758-8

Murray B, Pendleton L, Jenkins A, Sifleet S (2011) Green Payments for Blue Carbon: Economic Incentives for Protecting Threatened Coastal Habitats. In. Nicholas Institute for Environmental Policy Solutions, Duke University. p 43

Murray BC, Vegh T (2012) Incorporating blue carbon as a mitigation action under the United Nations Framework Convention on Climate Change: technical issues to address. In. Nicholas Institute for Environmental Policy Solutions, Duke University., Durham, NC.

Needelman BA, Emmer IM, Emmett-Mattox S, Crooks S, Megonigal JP, Myers D, Oreska MPJ, McGlathery K (2018) The Science and Policy of the Verified Carbon Standard Methodology for Tidal Wetland and Seagrass Restoration. Estuaries and Coasts 41(8): 2159-2171. https://doi.org/10.1007/s12237-018-0429-0

Parr JF, Sullivan LA (2005) Soil carbon sequestration in phytoliths. Soil Biology and Biochemistry 37(1): 117124. https://doi.org/10.1016/j.soilbio.2004.06.013

Pendleton L, Donato DC, Murray BC, Crooks S, Jenkins WA, Sifleet S, Craft C, Fourqurean JW, Kauffman JB, Marba N, Megonigal P, Pidgeon E, Herr D, Gordon D, Baldera A (2012) Estimating global "blue carbon" emissions from conversion and degradation of vegetated coastal ecosystems. PLoS One 7(9): e43542. https://doi.org/10.1371/journal.pone.0043542 
Prairie YT, Alm J, Beaulieu J, Barros N, Battin T, Cole J, Del Giorgio P, Delsontro T, Guérin F, Harby A, Harrison J, Mercier-Blais S, Serça D, Sobek S, Vachon D (2018) Greenhouse Gas Emissions from Freshwater Reservoirs: What Does the Atmosphere See? Ecosystems 21(5): 1058-1071. https://doi.org/10.1007/s10021-017-0198-9

Rillig MC (2018) Microplastic Disguising As Soil Carbon Storage. Environmental Science \& Technology 52(11): 6079-6080. https://doi.org/10.1021/acs.est.8b02338

Rodil IF, Attard KM, Norkko J, Glud RN, Norkko A (2019) Towards a sampling design for characterizing habitatspecific benthic biodiversity related to oxygen flux dynamics using Aquatic Eddy Covariance. PLoS One 14(2): e0211673. https://doi.org/10.1371/journal.pone.0211673

Rogers K, Saintilan N, Heijnis H (2005) Mangrove Encroachment of Salt Marsh in Western Port Bay, Victoria: The Role of Sedimentation, Subsidence, and Sea Level Rise. Estuaries 28(4): 551-559. http://www.jstor.org/stable/3526986

Rozaimi M, Fairoz M, Hakimi TM, Hamdan NH, Omar R, Ali MM, Tahirin SA (2017) Carbon stores from a tropical seagrass meadow in the midst of anthropogenic disturbance. Marine pollution bulletin 119(2): 253-260. https://doi.org/10.1016/j.marpolbul.2017.03.073

Santín C, Doerr SH, Preston CM, González-Rodríguez G (2015) Pyrogenic organic matter production from wildfires: a missing sink in the global carbon cycle. Global Change Biology 21(4): 1621-1633. https://doi.org/ $10.1111 /$ gcb. 12985

Serrano O, Lavery PS, Rozaimi M, Mateo MÁ (2014) Influence of water depth on the carbon sequestration capacity of seagrasses. Global Biogeochemical Cycles 28(9): 950-961. https://doi.org/10.1002/2014GB004872 Siikamäki J, Sanchirico JN, Jardine S, McLaughlin D, Morris D (2013) Blue Carbon: Coastal Ecosystems, Their Carbon Storage, and Potential for Reducing Emissions. Environment: Science and Policy for Sustainable Development 55(6): 14-29. https://doi.org/10.1080/00139157.2013.843981

Smith JN (2001) Why should we believe Pb-210 Sediment geochronologies? Journal of Environmental Radioactivity, 55: 121-123. https://doi.org/10.1016/s0265-931x(00)00152-1

Song J, Peng PA, Huang W (2002) Black Carbon and Kerogen in Soils and Sediments. 1. Quantification and Characterization. Environmental Science \& Technology 36(18): 3960-3967. https://doi.org/10.1021/es025502m Strayer DL, Glitzenstein JS, Jones C, Kolasa J, Likens GE, McDonnell M, Parker GG, Pickett STA (1986) Long term ecological studies: An illustrated account of their design, operation, and importance to ecology. In: Occasional Publication of the Institute of Ecosystem Studies. Millbrook, New York. 
Tokoro T, Hosokawa S, Miyoshi E, Tada K, Watanabe K, Montani S, Kayanne H, Kuwae T (2014) Net uptake of atmospheric $\mathrm{CO}_{2}$ by coastal submerged aquatic vegetation. Glob Chang Biol 20(6): 1873-1884. https://doi.org/10.1111/gcb.12543

Troxler T (2013) Integrated Carbon Budget Models for the Everglades Terrestrial-Coastal-Oceanic Gradient: Current Status and Needs for Inter-Site Comparisons. Oceanography 26(3): 98-107. https://doi.org/10.5670/oceanog.2013.51

UNFCCC (2015) Paris Agreement. In., United Nations.

Villa JA, Bernal B (2018) Carbon sequestration in wetlands, from science to practice: An overview of the biogeochemical process, measurement methods, and policy framework. Ecological Engineering 114: 115-128.

Weston NB, Neubauer SC, Velinsky DJ, Vile MA (2014) Net ecosystem carbon exchange and the greenhouse gas balance of tidal marshes along an estuarine salinity gradient. Biogeochemistry 120(1-3): 163-189. https://doi.org/10.1016/j.ecoleng.2017.06.037

Wilkinson GM, Besterman A, Buelo C, Gephart J, Pace ML (2018) A synthesis of modern organic carbon accumulation rates in coastal and aquatic inland ecosystems. Sci Rep 8(1): https://doi.org/10.1038/s41598-018$34126-y$

Wilson DP (1949) The Decline of Zostera Marina L. at Salcombe and its Effects on the Shore. Journal of the Marine Biological Association of the United Kingdom 28(2): 395-412.

Zang J, Liu S, Liu Y, Ma Y, Ran X (2016) Contribution of phytoliths to total biogenic silica volumes in the tropical rivers of Malaysia and associated implications for the marine biogeochemical cycle. Chinese Journal of Oceanology and Limnology 34(5): 1076-1084. http://dx.doi.org/10.1007/s00343-016-5116-z

Zimmerman AR, Canuel EA (2002) Sediment geochemical records of eutrophication in the mesohaline Chesapeake Bay. Limnology and Oceanography 47(4): 1084-1093. https://doi.org/10.4319/lo.2002.47.4.1084

Zinke L (2020) The colours of carbon. Nature Reviews Earth \& Environment 1(3): 141-141. https://doi.org/10.1038/s43017-020-0037-y 